\title{
7. Democracy in French Polynesia
}

\author{
Sémir Al Wardi
}

\section{La démocratie en Polynésie française}

La Polynésie est une « collectivité d'outre-mer » au sein de la République française. Sa culture politique présente des différences considérables par rapport à celle de la République et l'instabilité politique est l'une de ses caractéristiques principales. En effet, une « collectivité d'outre-mer » est une collectivité « spéciale » surtout parce que, contrairement aux autres collectivités, les lois de la République ne s'y appliquent que rarement, et ce selon le principe de la spécialité législative : par-dessus tout, ce territoire a le droit à l'indépendance. Par conséquent, puisque les anciennes colonies peuvent se séparer de la métropole, la vie politique tourne autour de ce droit à l'indépendance, ce qui inévitablement affecte leurs relations avec la métropole. Ainsi, cette vie politique est marquée par une division entre les indépendantistes et les autonomistes, même si cette division peut changer. La faiblesse idéologique et le nomadisme politique engendrent également l'instabilité politique. En outre, il semblerait que les concepts modernes du pouvoir, les relations entre les compétences nationales et les compétences locales, ne soient pas compris au sein de la société locale, qui semble elle-même assez réticente quand il s'agit d'adopter l'institutionnalisation.

\section{Introduction}

Polynesia is an 'overseas community' within the French Republic. French Polynesian political culture differs considerably from that of the Republic and political instability is one of its major characteristics. Indeed, an 'overseas community' is a 'special' community essentially because, unlike the other communities, the laws of the Republic apply to it only rarely, according to the principle of legislative speciality; ${ }^{1}$ above all this territory has the right to independence. Therefore since former colonies can break away, political life revolves around this right to independence, which inevitably affects its relations with France. So, political life divides between separatists and autonomists even

\footnotetext{
1 Due to this long-established principle, the laws are not fully applicable in former overseas territories. The law must expressly mention its applicability to a specified territory. As a consequence, overseas territories often become, as Yves Pimont says, 'the forgotten people of healthy reforms'. Worse, the practice of autonomy, in certain cases, even represents a regression compared to metropolitan France.
} 
if this divide can change. Ideological weakness and political nomadism also engender political instability. It would also seem that modern concepts of power, relations between national and local powers, are not understood within the local society, which itself seems to be rather reluctant to embrace institutionalisation.

\section{Polynesia is a Special 'Overseas Community' within the Republic}

The involvement of French colonies in national liberation, at the end of the Second World War, led to a new approach to overseas French dependencies in France. From then on, after 1946, there were 'French overseas departments' and 'French overseas territories', and no longer 'French colonies'. The words 'colonies' and even 'empire' were then abandoned forever. This abandonment signified also, the erasure of the reality those very words illustrated, as was the hope of L S Senghor (JORF, Assemblée Nationale Constituante, session of 11 avril 1946: 1729). The change from colony to territorial communities indicates that they fall within the purview of territorial communities, which stipulates that they are administered by elected councils.

'Overseas territories' from this time on consist of citizens and no longer of subjects. It was then that political life came into being in these territories. The minimum bottom line to any democracy, namely democratic representation (the Parliament and/or the executive represents the People and makes decisions on their behalf), the guarantee of public and individual liberties and the presence of one or several oppositions, is real in French Polynesia. The assembly is elected by direct universal suffrage and it is from this assembly that the executive members are chosen. Elections take place according to the rules of the Republic, the oppositions are represented (Tavini/Tahoeraa), and liberties guaranteed normally by the courts.

\section{The Right to Independence}

Former colonies, and overseas territories, can become independent by invoking Article 53 of the French Constitution. ${ }^{2}$ It is first necessary to consult the populations involved, then to ask the French Parliament to pass a law authorising the secession. In constitutional terms, overseas territories, today 'overseas communities', have enjoyed, as did colonies, 'a permanent right to

2 In its decision of 30 December 1975 relative to the Comoros affair, the Constitutional Council states that the provisions of Article 53, 'should be interpreted as being applicable not only if France were to cede a territory to a foreign State or should acquire one from it, but also should a territory cease to belong to the Republic and constitute an independent State or be attached to one'. 
independence' (Maestre and Miclo 1987: 1281). The Republic cannot therefore unilaterally declare an 'overseas community' independent. It has the power to decide on and to organise a referendum and even to choose its reading of the referendum (archipelago by archipelago or country-wide reading of the results), only the concerned populations can express their will to leave the Republic or not. The example of Mayotte has demonstrated that if the State wishes to disengage, but the population opposes it, then the territory remains French. On the other hand, if the population, after local elections, expresses a wish for emancipation, then it would seem that France would not oppose it. In other words, the former colonies have the possibility of becoming emancipated.

\section{The Pro-autonomy and Pro-independence Divide}

Since they can become emancipated from France, this is becoming a real 'obsession' for French Polynesian politicians. The constant possibility of separating from France has several consequences, the most important of which is to make political elites take sides on the matter of French presence: within (and in which ways) or without France (and again, in which ways); autonomy or independence. The Left/Right political divide does not exist in French Polynesia, only the line between pro-autonomy and pro-independence.

Originally structured around supporters of direct administration by France and proponents of internal autonomy (often labelled independents at the time), in the 1980s this division became a division between pro-autonomy and proindependence. The French Polynesian political universe is built on this issue. The political game revolves around French presence and the various territorial, or even national, elections are occasions for political parties to proclaim their position relative to the French presence issue. It seems that these are the only two categories in the French Polynesian political field, and the only ones driving ideological confrontations. Yet, the line can be blurred in everyday reality: politicians or voters can swing from one side to the other and back again, and make the divide considerably fuzzier. Even beyond the independence issue, it is the relationship of French Polynesia with France which dominates political thinking.

Unlike what happens in other territories of the French Republic, French Polynesian politicians do not look to the national issues for inspiration. Their indifference to national or 'metropolitan' politics does not mean that they are apolitical but rather that they focus on the local scene, the only one that matters. Therefore, political parties from the French mainland very seldom have a Polynesian extension.

This possibility of emancipation thus triggers a kind of statutory outbidding which has never known any rest since French Polynesians really started 
participating in political life. Gaston Flosse (2001) said that 'any institutional marking time would bring about, if applied, the death of our autonomy'. French Polynesia has statutes of 1957, 1977, 1984, 1996 and 2004, not counting the amendments of 1991 and 2007 and the major aborted reform of 'overseas countries' in 2000 .

\section{One People, One Nation?}

France recognises in its Constitution only one people and a single nation. Now, the French Polynesians consider that they are a different people from the French. This feeling strengthened with the granting of autonomy and especially its political symbols. These have been authorised since 1984, namely a flag, a seal, a hymn (Ia Ora o' Tahiti Nui), an Order of Tahiti (the decorations and titles resembling the French Legion of Honour), a protocol and a territorial holiday. Symbolic strength can be added by words such as 'country', 'Tahiti Nui', 'love of our people' and 'love of our country' commonly used in speeches... In fact, the French State is called 'hau farani' (French power) and French Polynesia 'hau fenua' (power of the country). The State is considered, from that time on, as an exogenous and temporary entity.

It is thus the strengthening of national feeling in French Polynesia which has characterised these last twenty years: autonomy and statutory outbidding have strengthened Tahitian nationalism, with the help of political symbols.

\section{Political Instability}

According to the Tahitian Academy, the Tahitian word for 'democracy' is 'Hau Manahune' (literally 'the power of the people'). Maco Tevane (2004), the president of the above-mentioned academy specified that "people should be understood as 'common people' (manahune) and that they were to be taken into account in the political system through its access to benefits". The 'ona' (the leaders) had to give some benefits to them.' It is this 'gift and counter-gift', a phrase beloved of anthropologists, which is perhaps at the origin of political patronage. Instability has always existed in Polynesia since the beginning of the political life in 1945. The only exception to this applies to the period 1996-2004, which was marked by a drift towards authoritarianism, with the complicity of the French state. 


\section{Ballots Full of Surprises}

Electoral results do not always reveal the new holder of power. Last minute alliances and political nomadism can result, as in 2008, in the loser winning, because in fact he became president of French Polynesia with the lowest score. In another scenario the one who wins the elections has no guarantee of holding power till the end of his/her mandate: examples are legion also in the Cook Islands, in Vanuatu, in the Papua New Guinea, in Solomon Islands, etc. In all these islands, elections do not represent a key moment in democratic life but simply one moment among others. We invest a lot of energy in elections, but immediately after the elections have taken place, the various political parties of the opposition constantly look for 'nomads' so as to take back power. In brief, a party which wins the elections can lose power in the days or the months which follow. The political fight does not become diminished after an election and patience, one of the conditions of democracy, does not exist.

Certainly, the proportional voting system has facilitated this instability following the example of the 4th Republic in France. Since 2004, for example, we have had nine presidents of French Polynesia, from two territorial elections, that is an average time in power of about eight months. But, as René Rémond (1991: 392) recalls, under the 4th Republic, 'the same group of men continuously exercises power'. It is the same in French Polynesia with the alternations since 2004. It is the same elected representatives who succeed one another, either alternately or together.

Is it necessary then to simply change the voting system to obtain stability? No, answers Georges Vedel in his Report on governmental instability in 1956 in France. It would only be one palliative among others 'completely powerless to fundamentally change things' (Chevallier 2001: 713).

The proposal, constantly renewed by French Polynesian politicians, to elect the president of French Polynesia by a direct universal suffrage system (JeanBaptiste Céran Jérusalémy, Gaston Flosse from 1985, Jean Juventin, Gaston Tong Sang) is not a solution. It would change nothing as in terms of instability: a representative elected in a direct universal suffrage system would only be able to be censured with difficulty by a local assembly, making it necessary, from then on, to set up a real Prime Minister who would represent the majority of the aforementioned assembly. The risk of 'cohabitation' is real and the problem is only moved to one side.

\section{Ideological Weakness and Nomadism}

Ideological weakness, marked by an economic and social policy common to the various independent or separatist political parties, facilitates political 
Politics, Development and Security in Oceania

nomadism. Politicians or the electorate can cross from one side to another one and conversely and so considerably blur the divide. French Polynesian elected representatives have often considered that they were free to use their mandate and so to join with any political party after their election. In other words, French Polynesian political culture gives a relative autonomy to elected representatives to negotiate their membership of a party according to their interests and especially to those of their electorate. Alliances even 'against nature' can exist. It is mostly a question of being the closest to public resources to redistribute to one's electorate or even to reactivate political patronage networks. This political nomadism has brought with it a chronic political instability since the beginning of political life in French Polynesia, with the exception of the period 1996 2004.

\section{An Emotive Relationship}

Democracy is not questioned as such in French Polynesia. Non-violent political instability, which is, let us recall, the hallmark of democracy, is explained by ideological weakness, political nomadism, the voting system and patronage. This latter is aggravated by the gaining of more and more power within the framework of the autonomy: it is this which has provided considerable power to redistribute public resources.

But this is possible only because its relationship to power remains personal even emotive. Can we say that French Polynesia, following the example of the Antilles, 'is the theatre of a persistent conflict - raised in particular by Aimé Césaire - between rational culture, the foundation of modernity, and emotional culture inherited from past...'? (Michalon 2006: 442). It seems indeed that it is an emotive relationship which wins the support of French Polynesians: it is enough to see the difference in the results during the elections between the metua (the guide) and any political fellow party member. Rudy Bambridge (1975), an influential French Polynesian politician, specified to the Secretary of State for French Overseas Departments and Territories, in 1975, that 'in French Polynesia more than elsewhere, politics is based on 'the affection' that the people have for their leaders. They are a sentimental people.'

It is also what explains the undoubted weight of mayors in the compiling of lists for territorial elections: every mayor, supposedly popular because he is one of those responsible for the redistribution of public resources, must be able to bring with him a certain number of votes for the person who heads the list who, once elected, will in his turn redistribute benefactions to the municipalities.

The fundamental consequence of this is the lack of institutionalisation. As emphasised by Max Weber in terms of legal and rational domination, this mode of domination which characterises western democracies leads to the prevention 
of power being exercised 'as personal privilege' (Braud 1985: 386). The leaders and their administrative departments are subject to the law and the citizens are treated in the same way whatever their affiliation. It is this equality of all in the eyes of the law which is 'central to the new society' (Michalon, in preparation). It is even the pivot of the republican values. However, the emotional link which allows one to acquire a good, even a symbolic one, thanks to personal relationships is in opposition to this equality upon which the State is built. It is the person who is important, not his/her function.

In French Polynesia, the relationship of power is based on this relationship of patronage and on personal exchange. This also explains that the electorate can follow a political leader even if he changes camp several times: it is not a question of things being decided rationally on questions of autonomy or independence, but often just with regard to a person's charisma.

For example, the mayor (Tavana) asks his population to vote for a specific candidate in Presidential elections. The population follows the mayor even if he is not logical, even if the mayor changes sides without explanation every election: ${ }^{3}$

Table 3: First Round of Presidential Election in Papeete

\begin{tabular}{|l|l|l|r|l|r|}
\hline Year & \multicolumn{1}{|c|}{$\begin{array}{c}\text { Election of } \\
\text { Mayor }\end{array}$} & \multicolumn{2}{c|}{$\begin{array}{c}\text { Score of socialist } \\
\text { candidates }\end{array}$} & \multicolumn{2}{c|}{$\begin{array}{c}\text { Score of conservative } \\
\text { candidates }\end{array}$} \\
\hline 1974 & F. Mitterrand & F. Mitterrand & $45.26 \%$ & $\begin{array}{l}\text { V. Giscard d'Estaing } \\
\text { J. Chaban Delmas }\end{array}$ & $\begin{array}{r}30.37 \% \\
20.58 \%\end{array}$ \\
\hline 1981 & V. Giscard d'Estaing & F. Mitterrand & $6.92 \%$ & $\begin{array}{l}\text { V. Giscard d'Estaing } \\
\text { J. Chirac }\end{array}$ & $64.05 \%$ \\
\hline 1988 & F. Mitterrand & F. Mitterrand & $52.40 \%$ & $\begin{array}{l}\text { J. Chirac } \\
\text { R. Barre }\end{array}$ & $24.26 \%$ \\
\hline 1995 & E. Balladur & L. Jospin & $12.69 \%$ & $\begin{array}{l}\text { E. Balladur } \\
\text { J. Chirac }\end{array}$ & $10.73 \%$ \\
\hline 2002 & J. Chirac & L. Jospin & $28.70 \%$ & $\begin{array}{l}\text { J. Chirac } \\
\text { F. Bayrou }\end{array}$ & $33.41 \%$ \\
\hline 2007 & N. Sarkozy & S. Royal & $39.47 \%$ & $\begin{array}{l}\text { N. Sarkozy } \\
\text { F. Bayrou }\end{array}$ & $54.02 \%$ \\
\hline
\end{tabular}

3 Tables from Jean-Marc Regnault, to appear in « L'hommage à Paul de Deckker ». 
Politics, Development and Security in Oceania

Table 4: Second Round of Presidential Election in Mahina

\begin{tabular}{|l|l|l|r|l|r|}
\hline Year & \multicolumn{1}{|c|}{$\begin{array}{c}\text { Election of } \\
\text { Mayor }\end{array}$} & \multicolumn{2}{c|}{$\begin{array}{c}\text { Score of socialist } \\
\text { candidates }\end{array}$} & \multicolumn{2}{c|}{$\begin{array}{c}\text { Score of conservative } \\
\text { candidates }\end{array}$} \\
\hline 1974 & F. Mitterrand & F. Mitterrand & $52.39 \%$ & $\begin{array}{l}\text { V. Giscard d'Estaing } \\
\text { J. Chaban Delmas }\end{array}$ & $\begin{array}{r}25.84 \% \\
17.54 \%\end{array}$ \\
\hline 1981 & V. Giscard d'Estaing & F. Mitterrand & $13.92 \%$ & $\begin{array}{l}\text { V. Giscard d'Estaing } \\
\text { J. Chirac }\end{array}$ & $\begin{array}{r}57.66 \% \\
21.14 \%\end{array}$ \\
\hline 1988 & F. Mitterrand & F. Mitterrand & $58.84 \%$ & $\begin{array}{l}\text { J. Chirac } \\
\text { R. Barre }\end{array}$ & $\begin{array}{r}24.38 \% \\
9.25 \%\end{array}$ \\
\hline 1995 & J. Chirac & L. Jospin & $13.99 \%$ & $\begin{array}{l}\text { E. Balladur } \\
\text { J. Chirac }\end{array}$ & $\begin{array}{r}22.40 \% \\
52.17 \%\end{array}$ \\
\hline 2002 & L. Jospin & L. Jospin & $40.07 \%$ & $\begin{array}{l}\text { J. Chirac } \\
\text { F. Bayrou }\end{array}$ \\
\hline 2007 & N. Sarkozy & tS. Royal & $37.83 \%$ & $\begin{array}{l}\text { N. Sarkozy } \\
\text { F. Bayrou }\end{array}$ & $\begin{array}{r}1.074 .92 \% \\
9.82 \%\end{array}$ \\
\hline
\end{tabular}

Nomadism is then possible because the divide really has no more meaning. Can we advance the hypothesis according to which only a referendum on self-determination would oblige French Polynesians to depersonalise political concepts? It is not sure, because emotive relations can take over again and the risk can be that the vote is determined with regard to a leader rather than a policy.

Close family and kin ties which we find in French Polynesia and on the other islands of the Pacific, is a serious handicap which hampers social relations. Thierry Michalon (in preparation) notes that for overseas French: 'the request for and the granting of privileges are considered as the normal and legitimate mode of relations with the administration, especially if it is concerns decentralized communities, administered by local elected representatives to whom everyone has affective links'. Once again, French Polynesians do not recognise institutions, but rather recognise people.

Furthermore, this lack of institutionalisation is often due to politicians who draw benefit from it. There would be thus an interest in maintaining this 'emotional' perception of politicians considered as suppliers of services, mostly in a private capacity. In other words, if this perception of power based on emotional links been a part of the Polynesian political culture, the elected representatives are going to maintain this relationship and encourage it so as to prevent the emergence of institutionalisation, for their own electoral benefit. We can again formulate the hypothesis that it is this emotive approach which limits the impact of convictions or gaol sentences: a convicted politician can always pursue his career either by being elected, or even recruited by those in power. A court decision does not seem to have same impact in a society based on personal exchange. 


\section{Looting Public Resources?}

Ideological weakness is also explained by a different vision of what constitutes the 'common good': it is a question of monopolising public resources for one's clan, one's group, one's party. One threatens to leave the government coalition if the rewards are not considered sufficient. Thierry Michalon (in preparation) explains that 'For these cultures, public institutions are not the place where decisions of general interest are taken and where public utilities are managed, but an unsupervised deposit of wealth to be divided up within the traditional networks of mutual assistance'. Power becomes, according to him, 'something edible'.

The people who French Polynesians call 'Islanders' (elected from outlying archipelagos), have these last few years beaten all records for political allegianceswitching and often broken political majorities, because of 'an insatiable appetite' for the public resources. President Oscar Temaru accuses them: 'I think that there are people who are here for their own personal interest, people there whom we know very well in this country, because they have a business on an island, because their wife is in such and such business, because they want to be a Minister of this or that or would like to become mayor' (Les Nouvelles, 13 October 2009). Moreover, elected representatives have a particular perception of ministries: there are 'technical' ministries and others which are 'political'. It is necessary to understand by 'political ministries', those which allow the establishment of a relationship of patronage and so to spread the linkages over the whole territory. And this is brokered in broad daylight, so that the various political groups, at the time of a governmental coalition, fight over these portfolios. The M.P. Bruno Sandras recognised, for example, regarding a Minister of Postal Services and Sports, that he has an interesting position: 'He has a comfortable portfolio which allows him to play politics for his party...' (Les Nouvelles, 27 January 2006).

Furthermore, there is a socio-economic dimension to power: this latter, thanks to the transfers from the State and to delegated powers, is an inescapable element in the economic and social game. It is this, for example, which distributes jobs, subsidies, diverse authorisations and work to companies: this dominant position has led to what the public prosecutor in Polynesia has called 'a pact of corruption'.

\section{Several Theoretical Approaches}

Three theories attract our attention: 'consensual' democracy, the lack of a 'Republic' and the organised chaos. 


\section{'Consensual' Democracy}

This is the theory advanced by Professor Boumakani (2008: $499 \mathrm{ff}$.) - Faculty of Law, Brazzaville - according to which, democracy should be consensual in more 'traditional' states and territories. All the decisions are taken in common by consensus. Nevertheless, we can advance that on one hand, political nomadism reduces this possibility and on the other hand, pre-European French Polynesia has never known consensus but was rather a violent society, constantly at war. Furthermore, democracy cannot be consensual because it supposes an opposition of expectations.

\section{The Lack of a Republic}

This is a constant subject: the lack of a 'political philosophy' to support democracy. Jean-Marc Regnault underlines that from the beginning of political life, 'the leaders of the RDPT (the Pouvana'a party) are little prepared for the management of public affairs and have thought little about democratic practices' (Tahiti Pacifique Magazine, October 2009, $\mathrm{n}^{\circ} 222$ : 36). Since French Polynesian political culture formed only at that time, in the 1950s, quite recently, thinking on this topic has not evolved very much. From then on, the new President of the Territorial Assembly, in 1953, Jean-Baptiste Céran-Jérusalémy 'tried to control everything to muzzle the opposition' (ibid.). Much later, former Minister of Finance Patrick Peaucellier also noted that Gaston Flosse had, in the 1990s, 'acted in such a way that the opposition was essentially abolished' (Tahiti Business $n^{\circ} 25$, September 2004).

Has there been a misunderstanding of the word 'democracy'? What is lacking is that rather long road towards republican democracy, which derives from the theory of a Social Contract, to consolidate the rights of the individual within the group or the clan, to impose human rights, and so to create a citizen detached from his affiliations (religious, geographical, ethnic, family, clan), to assert the love of equality and finally, with Raymond Aron, to demonstrate that the democracy is not confined only to the political domain but extends to economic development and to the protection of individual liberties (Hadas-Lebel 2002: 217). Liberal democracy, which is our political system, writes Pierre Manent, is 'the fruit of a very long elaboration, a very long distillation, so that it results from all our history, prolongs it and contains it. It is the formula discovered with difficulty thanks to which we have managed to live together in a more or less satisfactory way, us Europeans' (2007: 17). We can maintain that the concepts of 'modern State', of 'Republic' and 'democracy' collide, become confused, in determining modern political life. 
Therefore the problem would not be democracy but the absence of this very long process, rather complex, which carried forward this idea and which has, beyond the purely technical aspect of elections, forged a real political philosophy which has in turn made possible the government of the people.

But, in summary can we really blame the French Polynesians for this absence of a democratic philosophy?

First of all, we can wonder why the French Republic has not or not sufficiently introduced its values and principles into French Polynesia. During a session in the National Assembly, the majority and the opposition mutually blamed each other for having neglected the principles of the Republic in French Polynesia (Les Nouvelles de Tahiti, 29 January 2004.). France has not, moreover, introduced its values and principles into its colonies. A point common to all the overseas territories, in the years after the war, there was a demand for more equality and freedom. Philippe Braud (2004: 39) reminds us of the paradox: 'While the assertion of the universalist concept of human rights coincides in time with European expansion in the rest of the world, it has been nevertheless accompanied by extreme violence against native populations'. The absence of a real overseas policy, the constant of the Republic, combined with indifference, is going to keep these territories in zones without rights.

It even made the practice of democracy rather vague: Céran-Jérusalémy and the other French Polynesian politicians ask why France, while asserting democratic principles, arrested Pouvanaa a Oopa who voted 'NO', instead of 'YES', in the referendum of 1958, encouraged demonstrations against some leaders and prohibited them against others, and later, closed its eyes on that 'famous pact of corruption' of Gaston Flosse?

But, we can add also that the French Polynesians did not wish to be assimilated to the Republic but wanted an intermediate solution which allowed them to remain among themselves yet be under the umbrella of France. We can thus note collusion, even unconscious, between the State and French Polynesia in keeping the territory outside the values and the principles of the Republic.

Besides, this type of analysis obliges us to consider ideal political modernisation within a Western-style rationality: little by little, political life has to align itself with developments in metropolitan cities. But can we claim that democracy in France was and is perfect? That France would represent the cursor, the ideal democracy with which overseas territories should align themselves. The recentness of the democratic but unstable regimes of the 3rd and 4th Republic, the affairs of corruption under 3rd Republic, obliges us to be more modest. So, this proposition of the lack of a democratic philosophy remains insufficient. 
Politics, Development and Security in Oceania

\section{The Theory of 'Organised Chaos'?}

This theory draws attention to the mixture of the democratic principles and the practices proper to these societies. Political analysts, specialists of Africa, noticed that there was in these territories, in fact, an instrumentalisation of disorder' (Chabal and Daloz 1999: 177). It is a question of introducing democratic principles and of melding them again into a logic which fits in with the dominant universe of representations: 'registers are multiple even contradictory, without worrying about coherence' (ibid.: 172). Coherence is beyond us: We pass from one register to another according to circumstance. For example, in French Polynesia, political speeches in French and in Tahitian are not the same and involve different registers. Another example, in New Caledonia, Jean-Marie Tjibaou used 'procedures appropriate to every political and social organization' (Mokaddem 2008: 63). We also use honorifics, as opposed to institutionalisation, which imposes the depersonalisation of power, terms such as 'Big man', 'Metua' or even, in Africa, 'Lion'.

We also notice that the systematic research of a 'profit', and thus for a patronage, a reprehensible redistribution in the modern political game, is recognised by the whole population. If a dominant party no longer redistributes enough, it is replaced without compunction. It is moreover at the announcement of an impending fall of government that one of the members of the coalition will hammer the table that the government in power 'is incompetent' and/or 'ineffectual' in the redistribution of jobs or subsidies.

Furthermore, can we believe in 'citizenship', the foundation of democracy, in an essentially communal framework? In other words, community-based and patronage-driven systems are diametrically opposed to the logic 'of individual voters making electoral choices according to programs' (Chabal and Daloz 1999: 176). French Polynesian political parties represent the platform on which a recognised personality stands, much more than on any ideologybearing organisation. A party serves a man, not a program. This follows a logic which is not anti-democratic but rather one which follows a different line of reasoning. Can we claim, following the example of certain political analysts that 'modernisation' is possible without real 'westernization'? This, they add, 'is not easy to accept for a lot of people' (Chabal and Daloz 1999: 181). 


\section{Conclusion}

French Polynesian political life thus follows a logic which is to organise this 'disorder', to instrumentalise it for purposes of legitimisation. French Polynesia thus bases its legitimacy on a double approach: democratic legitimacy and redistribution of benefits within a personal relationship.

\section{References}

Bambridge, R. 1975. Archives, Letter of 16 April 1975

Boumakani, B. 2008. La prohibition de la " transhumance politique " des parlementaires. Etudes de cas africains, Revue française de Droit constitutionnel, $\mathrm{n}^{\circ} 75$.

Braud, P. 1985. Du pouvoir en général au pouvoir politique en particulier, in Traité de science politique (sous la dir. Madeleine Grawitz et Jean Leca, vol. 1, PUF.

Braud, P. 2004. Violences politiques. coll Essais, Points, éd. du Seuil, Paris.

Chabal, P., and Daloz, J-P. 1999. L'Afrique est partie! Du désordre comme instrument politique. Paris: Economica.

Chevallier, J-J. 2001. Histoire des institutions et des régimes politiques de la France, de 1789 à 1958. Paris: Armand Colin

Flosse, G. 2001. Speech to the Assembly of French Polynesia. Les Nouvelles de Tahiti (19 May)

Hadas-Lebel, Raphaël. 2002. Les 101 mots de la démocratie française. Paris: éditions Odile Jacob.

Maestre, J-C., and Miclo, F. 1987. La Constitution de la République Française. 2 édition. Paris: Economica

Manent, P. 2007. Enquête sur la démocratie. Paris: Gallimard

Michalon, T. 2006. L'affectivité contre la modernité? in Michalon, T. (sous la dir.). Entre assimilation et émancipation, l'outre-mer français dans l'impasse? Rennes: éd. Les Perséides.

Michalon, T. (in preparation). Les fondements socio-culturels de l'Etat moderne.

Mokaddem, H. 2008. Pratique et théorie Kanak de la souveraineté. NouvelleCalédonie: éditions Province Nord 
Politics, Development and Security in Oceania

Rémond, R. 1991. Notre siècle (de 1918 à 1991). Paris: Livre de poche, Fayard.

Tevane, M. 2004. Interview (director of the Académie tahitienne), 26 October. 